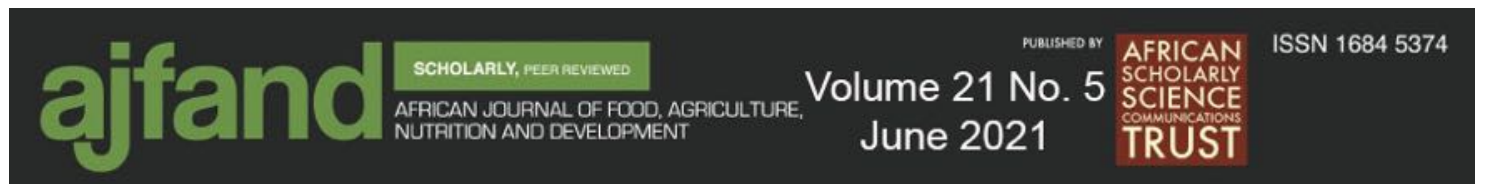

Afr. J. Food Agric. Nutr. Dev. 2021; 21(5): 18055-18065

https://doi.org/10.18697/ajfand.100.18100

\title{
USES OF PALMYRA PALMPLANT PARTS \\ IN THREE REGIONS OF EAST JAVA, INDONESIA
}

\author{
Saidi IA ${ }^{1 *}$, Efendi $N^{2}$, Azara $\mathbf{R}^{1}$, and L Hudi ${ }^{1}$
}

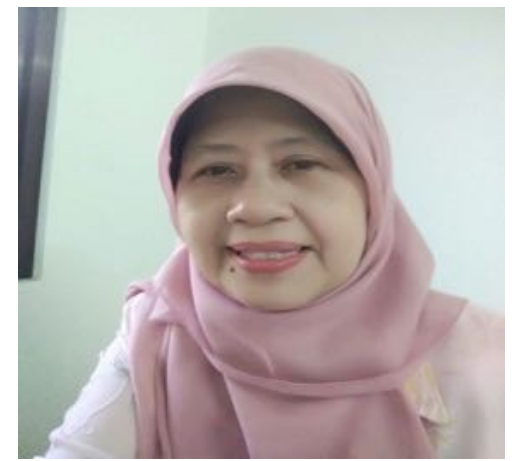

Ida Agustini Saidi

*Corresponding author email: idasaidi@yahoo.com

${ }^{1}$ Department of Food Technology, Universitas Muhammadiyah Sidoarjo, Jalan

Mojopahit 666 B, Sidoarjo 61215, East Java, Indonesia

${ }^{2}$ Department of Natural Science Education, Universitas Muhammadiyah Sidoarjo, Jalan Mojopahit 666 B Sidoarjo 61215, East Java, Indonesia 


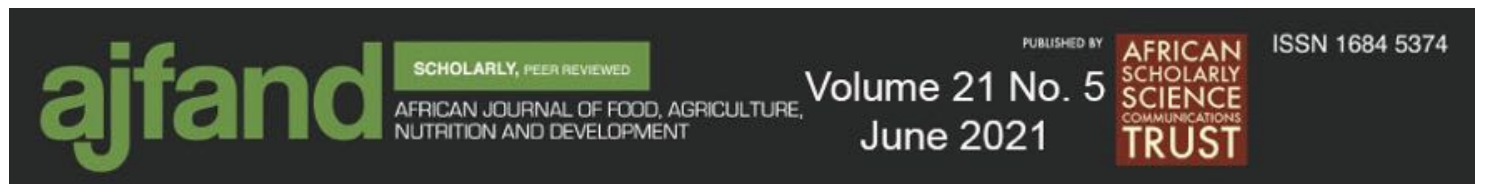

\begin{abstract}
Palmyra palm (Borassusflabellifer L.), is one of the palm trees highly associated with farmers in agro-forestry system in Indonesia. About 28,068 farmers cultivated 9,355 hectares of palmyra palm in East Java, Indonesia. Two regions which have highest palmyra palm in East Java are Sumenep in Madura islands and Tuban in East java mainland with production areas of about 5,535.70 and 1,832.45 hectares respectively. Pasuruan has special and well-known fresh palmyra palm sap, but there is scarcity of data on the number of plants or areas planted. However, development of industries at the area has displaced a large number of palmyras due to land use change. Field surveys were carried out at Gunungsari village, Beji district in Pasuruan, a single village of palmyra in Pasuruan; in the districts of Semanding and Palang in Tuban, and three districts, Pragaan, Lenteng, and Dungkek in Sumenep. One or two villages in Tuban and Sumenep were selected based on information from local official governments. A total of 180 palmyra farmers comprising of 30 farmers from each study district were interviewed. The interview solicited several information including the use of palmyra plant parts such as leaves, fruits, sap, trunks and other parts. Results of the study showed that there were several differences in the uses of palmyra palm plant parts across three regions in East Java. Uses of leaves, fruits, sap, trunks and other parts of palmyra palm varied in each region both on the type of use and on the percentage of each use. The differences may be as a result of different cultural characteristics of regions and populations studied. For instance, farmers in Pasuruan and Tuban use almost all plant parts just like those in East java mainland, and both regions have massive industrial development. Farmers in Sumenep, Madura differed mostly in their use of almost all parts of palmyra plant, especially leaves and sap. Leaves and sap appeared as most used parts in the three regions and have more commercial value than other parts. Uses of plant parts as traditional medicine and processed fruits seemed comparatively low in all the three regions. Based on the differences in characteristics of the utilization of plant parts in three regions of East Java, it appears that Pasuruan is superior in fresh sap; Tuban in fresh fruits and Sumenep Madura with jaggery and palmyra leaf weaving products and raw leaves.
\end{abstract}

Key words: Uses, plant parts, palmyra palm, Pasuruan, Tuban, Sumenep, East Java, Indonesia 


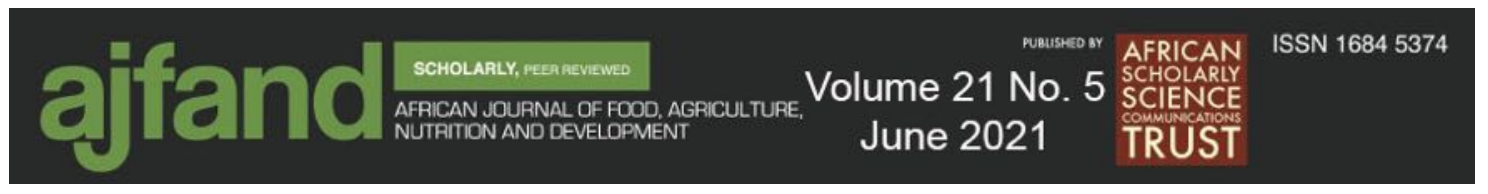

\section{INTRODUCTION}

Plants have been used for many purposes for several thousands of years. Palmyra as many other palms is one of the trees highly associated with farmers in agro-forestry system in Indonesia. Ethnobotanical researches on palmyra palm have been conducted in India as this plant was cultivated and naturalized throughout this country [1]. The uses of Palmyra palm among different tribal communities in India and ethnopharmacology have been compiled [2]. Utilization of Palmyra plant parts in Tamil Nadu State, India has been reported. The fruit and tuberous seedlings are used for food, beverage and sugar from the sap, fiber from the leaf and leaf base for brushes, cordage, weaving, and platting, trunk wood for construction and fuel, and numerous minor products [3]. Differences in culture from India and Indonesia, especially in East Java may allow differences in the use of palmyra palm. The exploitation of palmyra palm should get attention considering the potential of this plant as underdeveloped tropical plant resources. The ethnobotany study is needed and must be documented as people often learnt many fundamental principles and old-age wisdom from ethnic societies.

Palmyra palm (Borassusflabellifer L.) is known as a multipurpose species, so it is called "the tree with 801 uses in India" [2]. The plant has been used as a traditional irrigation system in Kerala, India [4], to prevent soil erosion and help recharge the water table [5]. Palmyra uses in rural areas in Andhra Pradesh, India are for leaves, fruits, timber, beverage, palmyra sprouts, fuel wood, paintings and medicinal use [6].

Palmyra palm (Borassusflabellifer L.), belongs to family Arecaceae and is a native of tropical Africa [1]. Borassus has a tropical distribution extending from West Africa through South Asia to Mainland Southeast Asia and eastern Indonesia [7]. The palmyra is a dioecious monocot plant with its single stem reaching $30 \mathrm{~m}$ in height and large fanshaped leaves spanning 1-3 $\mathrm{m}$ in diameter [8]. In Indonesia, palmyra palm found at coastal area which has dry climate, for example in Central Java (Brebes, Pekalongan, and Semarang), East Java (Tuban, Gresik, Lamongan), Madura, Bali (Karangasem and Buleleng), West Nusa Tenggara, East Nusa Tenggara, South Sulawesi and South East Maluku [9].

In East Java, about 28,068 farmers cultivated 9,355 hectares that included palmyra [10]. Within East Java, two regions with highest palmyra palm in the year 2017 are Sumenep in Madura island about 5,535,70 hectares [11] and Tuban in East Java mainland of 1,832,45 hectares [12]. There is also palmyra palm in Pasuruan, but data of planted area or number of palmyra palm plants were lacking. The palmyras are naturalized at the village of Gunungsari that is well-known for its palmyra fresh sap. However, development of industries at the area has displaced a large population of palmyras due to landuse change. Differences in the regions' characteristics may account for in differences in uses of plant parts. This ethnobotany study reports the regional differences of uses of palmyra palm by farmers. 


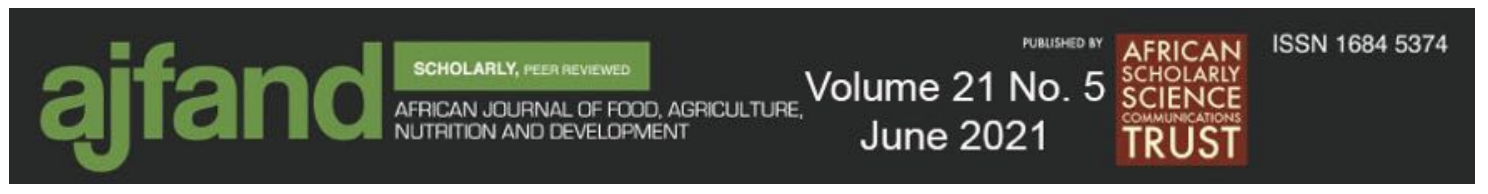

\section{MATERIALS AND METHODS}

\section{Study area}

The study was conducted in East Java Province, Indonesia which lies between $110^{\circ} 0^{\prime \prime}$ to $11^{\circ} 44^{\prime}$ Longitude and $7^{\circ} 12^{\prime \prime}$ to $8^{\circ} 48^{\prime \prime}$ Latitude and includes East Java mainland and the Madura Islands with total area of $47.963 \mathrm{~km}$ [10]. East Java is one of provinces in Indonesia where palmyra palm populations is quite high. Three regions were chosen depending on palmyra palms population, they are Pasuruan and Tuban in East Java mainland and Sumenep in Madura island. The three regions surveyed are Javanese in Tuban, Madurese in Sumenep, and Javanese and Madurese descended from Pasuruan. Figure 1 shows the three regions surveyed in this study.

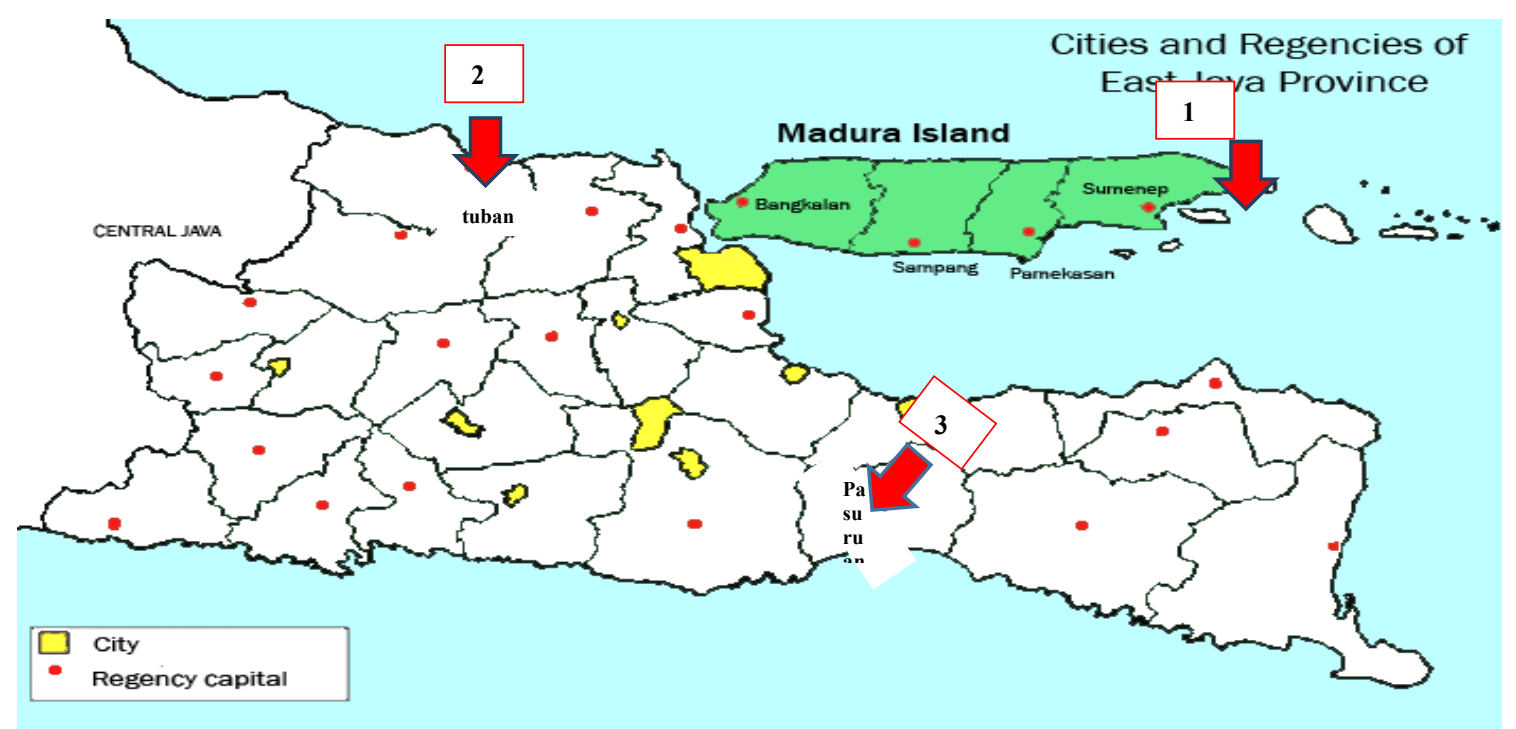

Figure 1: Palmyra palm ethnobotany study area in East Java

\section{Data collection and analysis}

Field surveys were carried out at Gunungsari village, Beji district in Pasuruan, a single village of palmyra in Pasuruan; Semanding and Palang in Tuban; and three districts Pragaan, Lenteng, and Dungkek in Sumenep. One or two villages in Tuban and Sumenep were selected based on data and information from local official governments. The study constituted 30 farmers or owners as informants in each district. Therefore, 180 palmyra palm farmers were interviewed in six districts in order to collect quantitative data of various uses of the plant parts. Interview officers in the three regions were recruited to facilitate communication in local language and assisted researchers to choose respondents in purposive sampling method. Structured interviews for deepening information were conducted for about two weeks in each district with questions about the use of Palmyra palm plant parts. Based on the data collected, most farmers of palmyra palms in the three regions were in the middle age (40-59 years old), about $69.5 \%$ were younger farmers (25-39 years old), $12.2 \%$ and $18.3 \%$ of the respondents were aged 60 years old and above, respectively. The data collected was then analyzed based on the methods of using plant parts in each region. The percentage 


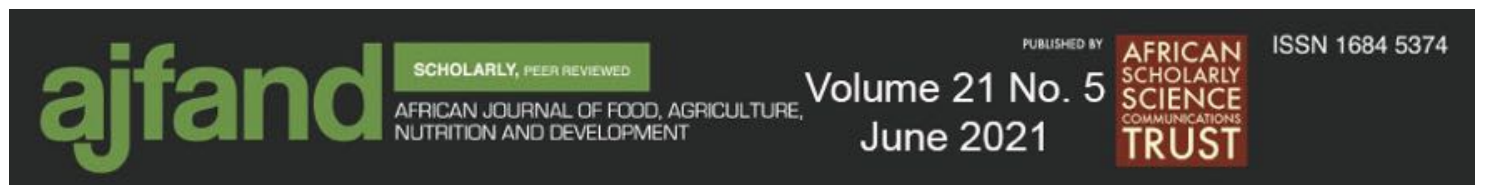

of the use of plant parts was obtained from the number that uses the methods divided by the number of people interviewed.

\section{RESULTS AND DISCUSSION}

Table 1 shows various uses of palmyra palm plant parts in three regions in East Java Province. Results of the study show that there were several differences in the uses of palmyra palm plant parts among the three regions in East Java (Table 1). All the sampled farmers at Gunungsari village in Pasuruan mostly used the leaves as food wraps, fresh fruit $(96.7 \%)$, fresh sap as beverage (100\%), trunk as building material $(60.0 \%)$, roost for traditional medicine $(3.3 \%)$ and dried parts as fuels $(60.0 \%)$.

Farmers in Sumenep mostly use leaves for weaving products such as mats and baskets (92.9\%), fresh fruits (74.4\%), sap as palm sugar or jaggery (65.7\%), trunk as building material $(98.9 \%)$, root sold as craft material $(10.0 \%)$, male inflorescence as traditional medicine (3.3\%) and dried parts as fuels (73.3\%). Similarly, all the farmers in Tuban mostly used leaves as food wraps and fresh fruit, fresh sap as beverage (93.3\%), trunk as building material (100.0\%), and dried parts as fuels (80.0\%).

\section{Uses of leaves}

All of Pasuruan and Tuban farmers used webbing palmyra palm leaves as food wraps for traditional foods such as: ketupat and lepetin, and dumbek in Tuban. Utilization of leaves in Sumenep most varied among the three regions. Besides use as food wraps for ketupat and lepet, leaves were also used for leaf weaving products such as mats and baskets. Mats are usually used for wrapping dried tobacco leaves as was the case in Sumenep, which is one of the great tobacco producing regions in East Java. Big baskets were used as crop harvesting containers and small baskets were used for jaggery mold. In Sumenep, it was also found that $63.3 \%$ of farmers sold raw young leaves to Bali. Balinese used the leaves for offerings, palm leaves writing, handicraft and other traditional uses. Only $15.6 \%$ of farmers used the leaves for roofing of huts and this was only found in district of Dungkek in Sumenep. In India, several tribes use the juice of the young leaves mixed with wateras traditional medicine to cure dysentery [9]

\section{Uses of fruits}

Fresh fruits as dessert is the most important and widespread use of palmyra fruit observed in all three regions in East Java. Only $11.7 \%$ farmers (Table 1b) processed the fruits as a mixture of dawet, a Javanese traditional dessert in Tuban. In Sumenep, $21.1 \%$ farmers did not use the palmyra fruits as they let the fruits fall from the tree. This is probably due to the use of leaves, which is more profitable than using fresh fruit. Only 3.3\% of farmers used fruit as traditional medicine in Gunungsari village, in Pasuruan district. This is different from other countries such as in Africa, where fresh fruit pulp is hand mashed, filtered and eaten raw or boiled with corn or porridge and usually used as an accompaniment to foods to give natural sweetness, aroma, and color [13]. Ripe fruit pulp can also be processed into soft beverages, jam, toffee, delicious food items and sweets [14]. In West Bengal, India, palmyra palm fruit pulp is processed into soru-chakli, a traditional food which is consumed in a particular season [15]. Palmyra palm fruit is also traditionally preserved as dried fruit pulp called "as pinattu" or "fruit leather" [16]. Flabelliferins, a compound contained in palmyra fruit 


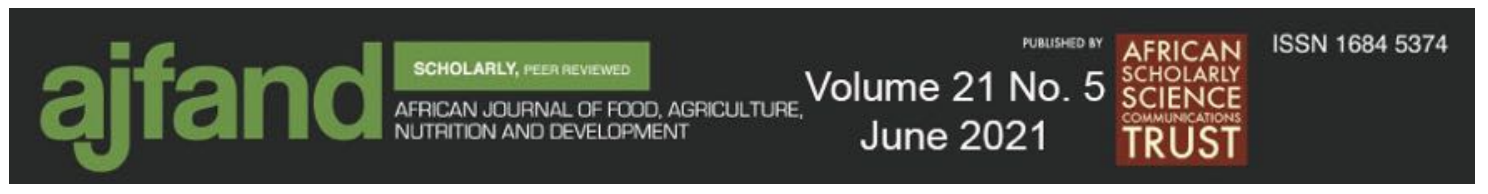

pulp now is proven to lower the glucose absorption into blood, increase the cardiac antioxidant activity and decrease the blood cholesterol [17].

\section{Uses of sap}

Table 1c. shows that sap in Pasuruan and Tuban is used as beverage, while in Sumenep, it is processedinto jaggery. In all the three regions, fresh sap is used as traditional medicine especially as a diuretic. Several tribes in Gujarat also use the fresh sap that collected early in the morning to cure tuberculosis [3]. Almost all of farmers in Pragaan and Dungkek processed their sap into jaggery, while those in the district of Lenteng in Sumenep processed it to liquid palm sugar. Liquid palm sugar is used as sweetener for boiled cassava or other foods for local uses. People in the district of Lenteng believe that palmyra sap in their area cannot be made into jaggery, but there is no research about the unique case. Toddy and vinegar are naturally processed from fermentation of fresh sap. Potential industrial use of sap is through bioconversion of palmyra sap into lactic acid and bioethanol production $[18,19]$.

\section{Uses of trunks}

Palmyra trunks were mostly used as building materials in the three regions (Table 1d). Only $4.4 \%$ of Sumenep farmers sold it for craft material and $6.7 \%$ of Tuban farmers processed it into wood canoes.

\section{Uses of other parts}

Table 1e. shows that only 3.3\% farmers of Gunungsari village in Pasuruan district used palmyra palm roots as traditional medicine, and 3.3\% of farmers in Dungkek district used the male inflorescence for making a traditional medicine to cure reproductive ailments. Research indicates that palmyra root contains bioactive ingredients for various applications like antioxidant, anti-inflammatory, antimicrobial, and anti-cancer activities [20]. Palmyra roots are also sold as craft material in Dungkek, Sumenep. However, none of the farmers in the three regions surveyed used the seedlings of palmyra. Hypocotyle axis of Borassus at the beginning of its germination is consumed boiled or roasted by the population of the Sahelian part of Africa [21]. In Sri Lanka, a shoot from a seedling may be boiled and dried and it is called "plukodiyal,", if the shoot is sundried, it is referred to as "odiyal." and both may be ground and sieved to give palmyra flour [22]. Dried parts, usually from leaves and fruit mesocarps are used as fuels in all the regions.

The differences in the use of palmyra plant parts maybe as a result of different cultural characteristics of the regions and populations studied. For instance, farmers in Pasuruan and Tuban use almost all the plant parts just like those in East Java mainland, maybe due to the massive industrial development of both regions. Farmers in Sumenep, Madura differed in their use of all parts of palmyra plant especially the leaves and sap. Leaves and sap are mostly used in the three regions and have more commercial value than other parts. Uses of plant parts as traditional medicine and processed fruits seem comparatively low in all three regions. 


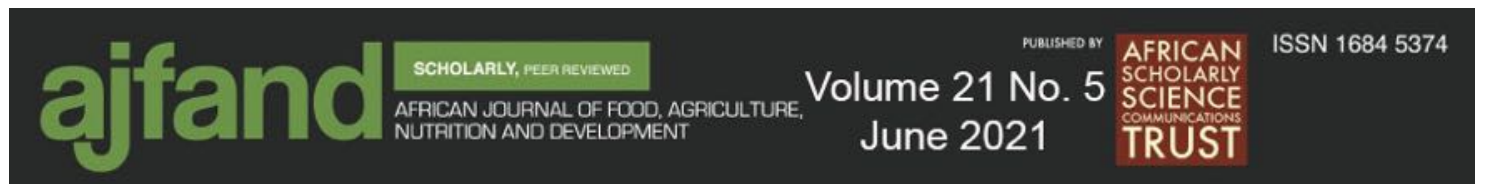

\section{CONCLUSION}

Survey data reported in this ethnobotany study showed that palmyra palm parts are used differently in the three selected regions of East Java, Indonesia. Differences in the uses of palmyra plant parts among the three regions maybe due to different characteristics of regions and populations. Farmers in Pasuruan and Tuban and those in the East Java mainland used almost all of plant parts for similar purposes. This may be attributed to the fact that both regions have large industrial development. Farmers in Sumenep, Madura varied in using all parts of palmyra plant, especially leaves and sap. Leaves and sap appeared to be most widely used in the three regions and had more commercial value than other parts. Uses of plant parts as traditional medicine and processed fruits are comparatively low in all the three regions.

Based on the differences in characteristics of the utilization of plant parts in the three regions of East Java, it appears that Pasuruan is superior in the use of fresh sap from palmyra plant, Tuban in fresh fruits and Sumenep, Madura with jaggery and palmyra leaf weaving products and raw leaves. These results can be used as the basis for palmyra palm development policies in each region.

\section{ACKNOWLEDGEMENTS}

The authors would like to acknowledge The Ministry of Research Technology and Higher Education of Indonesia for funding this study under University Superior Basic Research fund entitled "Exploration of palmyra palm (Borassusflabellifer L.) as food resource potentials in East Java" 


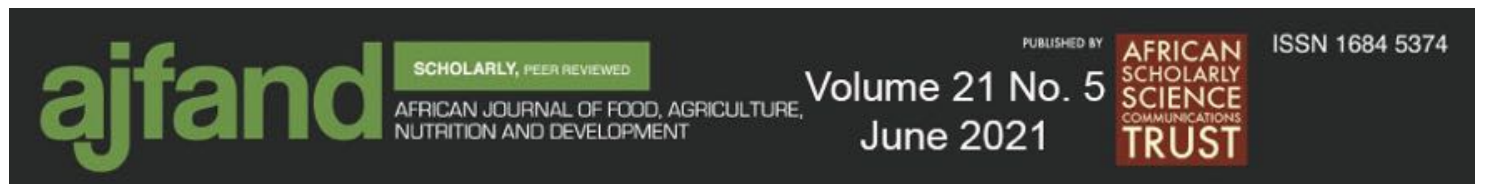

Table 1: Uses of parts of palmyra palm tree in three regions of East Java (in percentage)

a. Leaves

\begin{tabular}{|c|c|c|c|c|c|c|c|c|c|}
\hline \multirow[t]{3}{*}{ Region } & \multicolumn{9}{|c|}{ Leaves } \\
\hline & \multicolumn{2}{|c|}{ Raw leaves } & \multicolumn{2}{|c|}{ Food wraps } & \multicolumn{2}{|c|}{$\begin{array}{l}\text { Leaf weaving } \\
\text { products }\end{array}$} & \multicolumn{2}{|c|}{$\begin{array}{l}\text { Roofing } \\
\text { huts }\end{array}$} & \multirow{2}{*}{$\begin{array}{l}\text { Not } \\
\text { used }\end{array}$} \\
\hline & All & Sold & All & Sold & All & Sold & All & Sold & \\
\hline Pasuruan & - & - & 100.00 & 100.00 & - & - & - & - & - \\
\hline Sumenep & 63.32 & 63.32 & 56.66 & 56.66 & 92.22 & 92.22 & 15.56 & & \\
\hline Tuban & - & - & 100.00 & 100.00 & - & - & - & - & - \\
\hline
\end{tabular}

b. Fruits

\begin{tabular}{|c|c|c|c|c|c|c|c|c|c|}
\hline \multirow[t]{3}{*}{ Region } & \multicolumn{9}{|c|}{ Fruits } \\
\hline & \multicolumn{2}{|c|}{$\begin{array}{ll}\text { Fresh Fruits } \\
\text { (dessert) }\end{array}$} & \multicolumn{2}{|c|}{ Processed } & \multicolumn{2}{|l|}{ Feed } & \multicolumn{2}{|c|}{$\begin{array}{l}\text { Traditional } \\
\text { medicine }\end{array}$} & \multirow[t]{2}{*}{$\begin{array}{l}\text { Not } \\
\text { used }\end{array}$} \\
\hline & All & Sold & All & Sold & All & Sold & All & Sold & \\
\hline Pasuruan & 96.67 & 96.67 & - & - & - & - & 3.33 & 3.33 & 3.33 \\
\hline Sumenep & 74.44 & 22.22 & & & 12.22 & - & - & - & 21.11 \\
\hline Tuban & 100.00 & 83.33 & 11.67 & 11.67 & - & - & - & - & - \\
\hline
\end{tabular}

c. Sap

\begin{tabular}{|c|c|c|c|c|c|c|c|c|c|}
\hline \multirow[t]{3}{*}{ Region } & \multicolumn{9}{|c|}{ Sap } \\
\hline & \multicolumn{2}{|c|}{$\begin{array}{l}\text { Beverages } \\
\text { (fresh sap) }\end{array}$} & \multicolumn{2}{|c|}{$\begin{array}{l}\text { Toddy } \\
\text { vinegar }\end{array}$} & \multicolumn{2}{|c|}{$\begin{array}{l}\text { Palm sugar } \\
\text { (Jaggery) }\end{array}$} & \multicolumn{2}{|c|}{$\begin{array}{l}\text { Liquid palm } \\
\text { sugar/other } \\
\text { processed }\end{array}$} & $\begin{array}{l}\text { Not } \\
\text { used }\end{array}$ \\
\hline & All & Sold & All & Sold & All & Sold & All & Sold & \\
\hline Pasuruan & 100.00 & 100.00 & 3.33 & 3.33 & - & - & - & - & - \\
\hline Sumenep & 13.33 & 10.00 & 50.00 & 50.00 & 65.56 & 65.56 & 32.22 & 32.22 & \\
\hline Tuban & 93.33 & 93.33 & 43.33 & 43.33 & 1.67 & 1.67 & 5.00 & 5.00 & \\
\hline
\end{tabular}




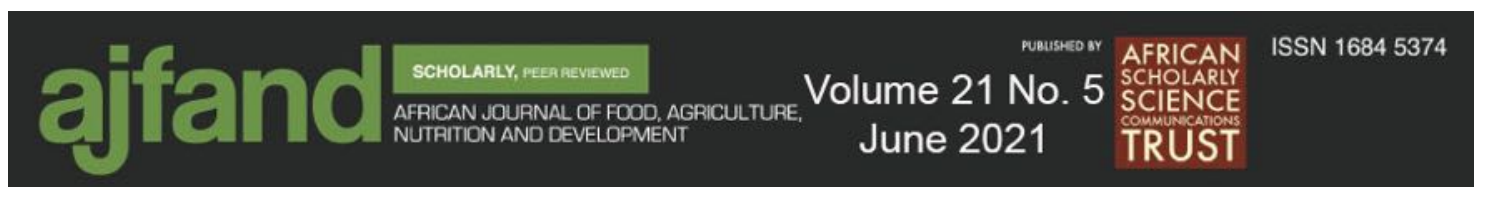

d. Trunks

\begin{tabular}{|c|c|c|c|c|c|c|c|c|c|}
\hline \multirow[t]{4}{*}{ Region } & \multicolumn{9}{|c|}{ Trunks } \\
\hline & \multirow{2}{*}{\multicolumn{2}{|c|}{$\begin{array}{l}\text { Building } \\
\text { material }\end{array}$}} & \multirow{2}{*}{\multicolumn{2}{|c|}{$\begin{array}{l}\text { Craft } \\
\text { material }\end{array}$}} & \multirow{2}{*}{\multicolumn{2}{|c|}{ Fuel }} & \multirow{2}{*}{\multicolumn{2}{|c|}{ Wood canoe }} & \multirow{3}{*}{$\begin{array}{l}\text { Not } \\
\text { used }\end{array}$} \\
\hline & & & & & & & & & \\
\hline & All & Sold & All & Sold & All & Sold & All & Sold & \\
\hline Pasuruan & 60.00 & 13.33 & - & - & 40.00 & 10.00 & - & - & 6.67 \\
\hline Sumenep & 98.89 & 13.26 & 4.44 & 4.44 & 2.22 & & & & 1.11 \\
\hline Tuban & 100.00 & 18.33 & & & & & 6.66 & 5.00 & \\
\hline
\end{tabular}

\section{e. Other parts}

\begin{tabular}{lllll}
\hline Region & \multicolumn{3}{c}{ Parts } \\
\cline { 2 - 5 } & Root & Seedling & Inflorescence & Dried parts \\
\hline Pasuruan & Trad. Medicine & - & - & Fuel $(60.00 \%)$ \\
& $(3.33 \%)$ & & \\
\hline Sumenep & Craft material (10 & & Trad.medicine(3. & Fuel $(73.33 \%)$ \\
& $\%)$ & & $33 \%)$ & \\
\hline Tuban & - & - & - & Fuel $(80.00 \%)$ \\
\end{tabular}




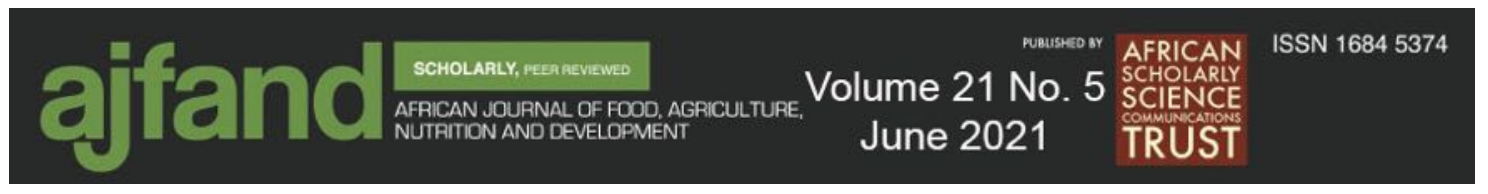

\section{REFERENCES}

1. Gummadi VP, Battu GR, Diyya $K$ and $K$ Manda A review on palmyra palm (Borassusflabellifer). Int. J. Curr. Pharm. Res. 2016; 2:17-20.

2. Thakur NS, Attar SK, Gunaga RP, Chouhan RS, Hedge HT and JB Bhusara Anecdote about Mythology and ethno-pharmacology of Asian Palmyra Palm (Borassusflabellifer L.). Nat. Conf. Palmyra Palm. 2016:80-93.

3. Davis TA and DV Johnson Current utilization and further development of the palmyra palm (Borassusflabellifer L., Arecaceae) in Tamil Nadu State, India. Econ. Bot., 1987; 2: 247-266.

4. Ramachandran VS, Swarupanandan $\mathbf{K}$ and $\mathbf{C}$ Renuka A traditional irrigation system using palmyra palm (Borassusflabellifer) in Kerala, India. Palms, 2004; 4: 175-181.

5. Jana $\mathbf{H}$ and $\mathbf{S}$ Jana Palmyra palm: Importance in Indian agriculture. RashtriyaKrishi, 2017; 2: 35-40.

6. Bhaskar K Borassusflabellifer L. A tree behind the forest with multiple uses in rural areas: A case study from Nellore district, Andhra Pradesh, India. Imperial J. Interd. Res. (IIJR), 2017; 5: 1486-1493.

7. Eagleton GE Review: Persistent pioneers; Borassus L. and Corypha L. in Malesia. Biodiversitas, 2016;2: 716-732.

8. Sakulsathaporn A, Wonnapinji $\mathbf{P}$ and $\mathbf{S}$ Vuttipongchaikij The complete chloroplast genome sequence of Asian Palmyra palm (Borassusflabellifer). BMC Res Notes, 2017; 740: 2-7.

9. Tambunan $\mathbf{P}$ The potential and policy for palmyra palm development to increase the people income. JurnalAnalisisKebijakanKehutanan. 2010;71: 27-45

[Indonesian].

10. Central Agency on Statistic of East Java Province. JawaTimur Province in figures,2017, Central agency on Statistics of East Java Province, Surabaya. [Indonesian].

11. Statistics of Sumenep Regency. Sumenep in figures,2017, Statistics of SumenepRegency[Indonesian].

12. Statistics of TubanRegency. Tuban Regency in figures,2017, Statistics of TubanRegency[Indonesian].

13. Abe- Inge V, Agbenorhevi JK, Kpodo FM and OA Adzinyo Effect of different drying techniques on quality characteristics of African palmyra palm (Borassusaethiopum) fruit flour. Food Res. 2018;2018: 1-9. 


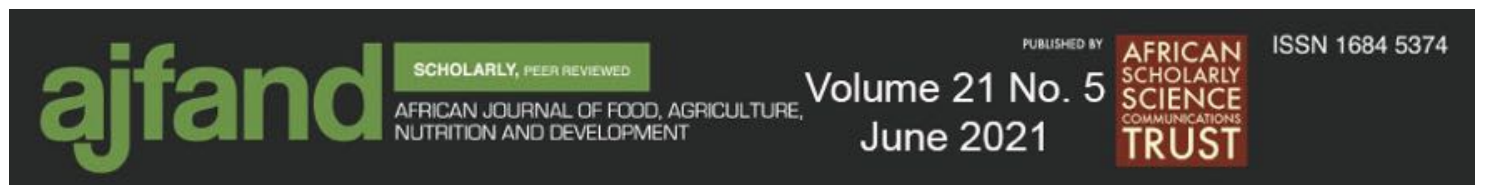

14. Chaurasiya AK, Chakraborty I and J Saha Value addition of Palmyra palm and studies on the storage life. J. FoodSci. Technol., 2014; 4: 768-773.

15. Prabhakar PK and PP Srivastav Characterization of soru-chakli - a traditional food of West Bengal. Intern. J. Food Sci. Technol.2015; 1 1:1-8.

16. Srishankar S, Subajini M, Wijesingh WAJP, Bandara SMIPG and SS Vijeindran Comparative analysis of the proximate composition of palmyrahpinattu and flours (odiyal, boiledodiyal). Int. J. Environ. \& Agric. Res., 2017;6: 57-60.

17. Sangheeta S, Wansapala MAJ, Gnanasharmala A and S Srivijeindran Optimization of palmyrah (Borassusflabellifer) fruit pulp in different varieties of fruit yoghurts. Int. J. Multid. Stud., 2014; 1: 91-103.

18. Chooklin S, Kaewsichan $\mathbf{L}$ and $\mathbf{J}$ Kaewsrichan Potential use of

Lactobacilluscasei TISTR 1500 for the bioconversion of palmyra sap to lactic acid. J. Sust. Energy \& Environ., 2011; 2: 83-87.

19. Arunavathi S, Palanivelu P and K Veluraja A new technology for extraction of palm sap from palmyrah tree for bioethanol production. Elixir Appl. Bot., 2012; 2012: $9612-9615$.

20. Subashini S, Rameshkannan V and P Mani Phytochemical and GC-MSanalysis of bioactive compounds from Borassusflabellifer Linn root. Eur. J. Mol.

Biol.Biochem., 2015;3: 148-152.

21. Ali A, Fadimatou B, Tchiegang C, Saidou C and MB Adji Physico-chemical and functional properties of batchi or hypocotyle axes of Borassusaethiopum Mart. Afr. J. Food Sci., 2010;10: 635-641.

22. Janz ER, Wicremasekara NT and KAV Sumuduni A review of the chemistry and biochemistry of seed shoot flour and fruit pulp of the palmyrah palm (Borassusflabellifer L.). J. Natn. Sci. Foundation Sri Lanka, 2002;1\&2: 61-87. 